\title{
DEVELOPMENT OF GAS CHROMATOGRAPHY-MASS SPECTROMETRY FINGERPRINTS FOR WARBURGIA UGANDENSIS HERBAL MATERIALS
}

\author{
ONYAMBU MESHACK $0^{1 *}$, GIKONYO NICHOLAS $\mathrm{K}^{1}$, NYAMBAKA HUDSON N², \\ THOITHI GRACE N ${ }^{3}$ AND OKUMU TOM O ${ }^{4}$ \\ 'Department of Pharmacognosy and Pharmaceutical Chemistry, School of Pharmacy, \\ Kenyatta University, Nairobi, Kenya \\ ${ }^{2}$ Department of Chemistry, School of Pure and Applied Sciences, Kenyatta University, \\ Nairobi, Kenya \\ ${ }^{3}$ Department of Pharmaceutical Chemistry, School of Pharmacy, University of Nairobi, \\ Nairobi, Kenya \\ ${ }^{4}$ Kenya Bureau of Standards, Nairobi, Kenya
}

Published online: 23 November 2021

To cite this article: ONYAMBU MESHACK O, GIKONYO NICHOLAS K, NYAMBAKA HUDSON N, THOITHI GRACE N \& OKUMU TOM O (2021) Development of gas chromatography-mass spectrometry fingerprints for Warburgia ugandensis herbal materials, Malaysian Journal of Pharmaceutical Sciences, 19(2): 23-46. https://doi.org/10.21315/mjps2021.19.2.2

To link to this article: https://doi.org/10.21315/mjps2021.19.2.2

\begin{abstract}
Warbugia ugandensis (W. ugandensis) is among the 10 most utilised medicinal plants in East Africa. Stem bark and leaves are used as remedies for malaria, stomachache, coughs and skin diseases. Consequently, the plant is endangered because of uncontrolled harvest and lack of domestication. There is therefore fear of poor quality commercialised products due to lack of evaluation mechanisms. This study explored the chemical profiles that could be used to confirm its authenticity and purity. W. ugandensis used as reference during method development was harvested from Kenyatta University Medicinal Plant Research Garden (KUMPRG). Six other samples were obtained from different geographical locations in Kenya. The samples were identified by a botanist and a voucher specimen (MO/002008/2013) deposited in the East African Herbarium, National Museums of Kenya, Nairobi. Samples were harvested and processed by World Health Organization (WHO) recommended methods. Chromatographic profiles of the leaf and stem bark were established based on parameters arrived at iteratively. The study characterised over 100 compounds in the leaf and stem bark. Based on area percent and known medicinal value, 22 compounds from the leaf and 38 from the stem bark were selected as major chemical profiles. The compounds in the stem bark included gamma-sitosterol $(1.0 \%-2.5 \%)$, squalene $(0.2 \%-4.6 \%)$, isolongifolene $(1.2 \%-2.8 \%)$, phenol $2-m e t h o x y(0.8 \%-1.8 \%)$ and nerolidol $(0.3 \%-1.5 \%)$. Those in the leaf included nerolidol $2(0.3 \%-1.1 \%)$, phytol $(0.6 \%-1.7 \%)$, 2-methoxy phenol $(0.2 \%-$ $2.2 \%)$, gamma-tocopherol $(0.2 \%-0.9 \%)$, vitamin $E(0.4 \%-1.5 \%)$ and gamma-sitosterol
\end{abstract}

*Corresponding author: onyambu.meshack@ku.ac.ke

(c) Penerbit Universiti Sains Malaysia, 2021. This work is licensed under the terms of the Creative Commons Attribution (CC BY) (http://creativecommons.org/licenses/by/4.0/). 
$(1.8 \%-4.9 \%)$. Most of these compounds were characterised in W. ugandensis for the first time. The profiles therefore can form fingerprints for use to evaluate its quality, purity and authenticity.

Keywords: Chromatographic fingerprints, Warbugia ugandensis, Quality

\section{INTRODUCTION}

Warbugia ugandensis ( $W$. ugandensis) is a spreading evergreen tree $4.5 \mathrm{~m}-30 \mathrm{~m}$ tall from the division Magnoliophyta, order Canellales and family Canelliacea. It has a long history of ethnomedical use and commercialisation in East Africa. In Kenya, single and poly-herbal formulations from the plant are sold in supermarkets, herbal clinics and open-air markets for therapeutic use against Malaria and various microbial infections (Onyambu et al. 2019). Scientific studies support its use against these ailments in addition to stomachache among others (Beentje 1994; Muchugi et al. 2006). European medicines agency (European Medicines Agency 2011) recommends that herbal products that have been medicinally used for a long time and are considered not harmful under normal conditions of use, should be standardised. Neeraj and Bhupinder (2011) describe standardisation as an important step for the establishment of a constant biological activity, a consistent chemical profile or a quality assurance programme for production and manufacturing of widely used herbal drugs. The major aspects that should be established in standardisation and quality assurance of herbal medicines include botanical, physicochemical, biological and chemical characteristics (World Health Organization [WHO] 1998). Previous studies have determined some of these aspects as relates to quality evaluation of $W$. ugandensis (Onyambu et al. 2020). Because the therapeutic activity of herbal formulations depends on their phytochemical constituents, there is need to explore chromatography as a quality standardisation tool in $W$. ugandensis herbal materials. Previous studies have advocated for gas chromatographymass spectrometry (GC-MS) as the best presently available, non-sophisticated and feasible tool for quality proof of herbal drugs (Jian, Rui and Shengmao 2010).

A review by Khoddami, Meredith and Thomas (2013) shows numerous applications of gas chromatography in separation, identification and quantification of phenolic compounds in plants including condensed tannins and flavonoids. Results from these techniques provide a chemical fingerprint as to the nature of chemicals or impurities present in the plant extract (WHO 2002).

A fingerprint is a specific profile or pattern which chemically represents a sample based on the detected compounds (Alaerts et al. 2010; Tistaert, Dejaegher and Vander 2011). Chromatographic fingerprints are therefore chromatograms which represent the chemical characteristics of a herbal product (Fan et al. 2006). In addition, samples with similar chromatographic fingerprints are likely to have similar chemical and pharmacological properties (Fan et al. 2006; Alaerts et al. 2010). The importance of using this technique to consider multiple constituents in the herbal drug extract as opposed to individually considering one or two markers for evaluating the quality of herbal extracts has been emphasised before (Fan, Yi-Zeng and Reishan 2003; Liang, Xie and Chan 2004; Xie et al. 2006). This is because the efficacy of herbal products is dependent on the concentration of many bioactive compounds (Tistaert, Dejaegher and Vander 2011). Chromatographic fingerprinting technique has been applied for quality evaluation of many herbal products (Alaerts et al. 2007; Ji et al. 2005; Xu et al. 2009; Lekhooa et al. 2012; Yun-Li et al. 2011).

Malay J Pharm Sci, Vol. 19, No. 2 (2021): 23-46 
This study therefore explored the use of gas chromatography-mass spectrometry (GC-MS) to develop chemical profiles that would be used as fingerprints for evaluating the quality, authenticity and consistency of $W$. ugandensis based herbal materials. Previous studies have reported highly contaminated and or substituted herbal materials being sold in Kenyan markets (Onyambu et al. 2013). Determination of GC-MS fingerprints will contribute to knowledge of chemical patterns that may be involved in synergistic therapeutic activity and enhance effective quality control, besides providing key information on how geographical zones affect quality of herbal drugs based on $W$. ugandensis.

\section{METHODS}

\section{Study Area}

W. ugandensis from Kenyatta University Medicinal Plant Research Garden (KUMPRG) was used as a reference material to develop chromatographic fingerprinting method for quality evaluation. Medicinal plants in KUMPRG are cultivated using WHO guidelines for good agricultural practices (WHO 2003) thereby making the sample suitable for use as a reference material in the study. Other $W$. ugandensis samples were obtained from six different geographical locations in Kenya which are based on the distribution of the flora in East Africa. The chosen areas favour growth of $W$. ugandensis species. Table 1 shows the exact location and altitude of areas where the plant samples used in the study were collected. In Kenya W. ugandensis only grows in five geographical zones (Beentje 1994; Dharani 2002). The zones shown in the map (Figure 1) include K3, K4, K5, K6 and K7, covering the Coast of Kenya, Rift valley, Nyanza, Central and Nairobi areas. The Northern frontier and parts of Turkana (K1 and K2) do not support its growth.

Table 1: Physical, geographical location, altitude and date of sample collection.

\begin{tabular}{|c|c|c|c|}
\hline No. & Location & $\begin{array}{l}\text { Altitude }(\mathrm{M}) \text { and } \\
\text { geographicalzone }(\mathrm{K})\end{array}$ & Date of harvesting \\
\hline 1 & $\begin{array}{l}\text { Near Nyalibridge, Mombasa } \\
\text { county }\end{array}$ & $18 \mathrm{M}, \mathrm{K} 7$ & $18 / 05 / 2014$ \\
\hline 2 & $\begin{array}{l}\text { Mauforest, Transmara, near } \\
\text { Kilgoristown, Narok county }\end{array}$ & 1950 M, K6 & 08/05/2015 \\
\hline 3 & $\begin{array}{l}\text { Masimba, along the river near } \\
\text { Masimba town, Kisii county }\end{array}$ & $1770 \mathrm{M}, \mathrm{K} 5$ & 29/05/2015 \\
\hline 4 & $\begin{array}{l}\text { Near Moi International Airport, along } \\
\text { the Kapsabet-Eldoret road, Uasin } \\
\text { Gishu county }\end{array}$ & $2150 \mathrm{M}, \mathrm{K} 3$ & 05/06/2015 \\
\hline 5 & $\begin{array}{l}\text { Eastern slopes of Mt Kenya, } \\
\text { Ngariama location, Wakaburu } \\
\text { village, Kirinyaga county }\end{array}$ & $1800 \mathrm{M}, \mathrm{K} 4$ & $21 / 06 / 2015$ \\
\hline 6 & $\begin{array}{l}\text { Njoro river near Egerton University } \\
\text { Nakuru county }\end{array}$ & $1890 \mathrm{M}, \mathrm{K} 3$ & $10 / 07 / 2015$ \\
\hline S & $\begin{array}{l}\text { Kenyatta University Medicinal Plant } \\
\text { Research Garden, Nairobi county }\end{array}$ & $1670 \mathrm{M}, \mathrm{K} 4$ & 23/09/2013 \\
\hline
\end{tabular}

Malay J Pharm Sci, Vol. 19, No. 2 (2021): 23-46 


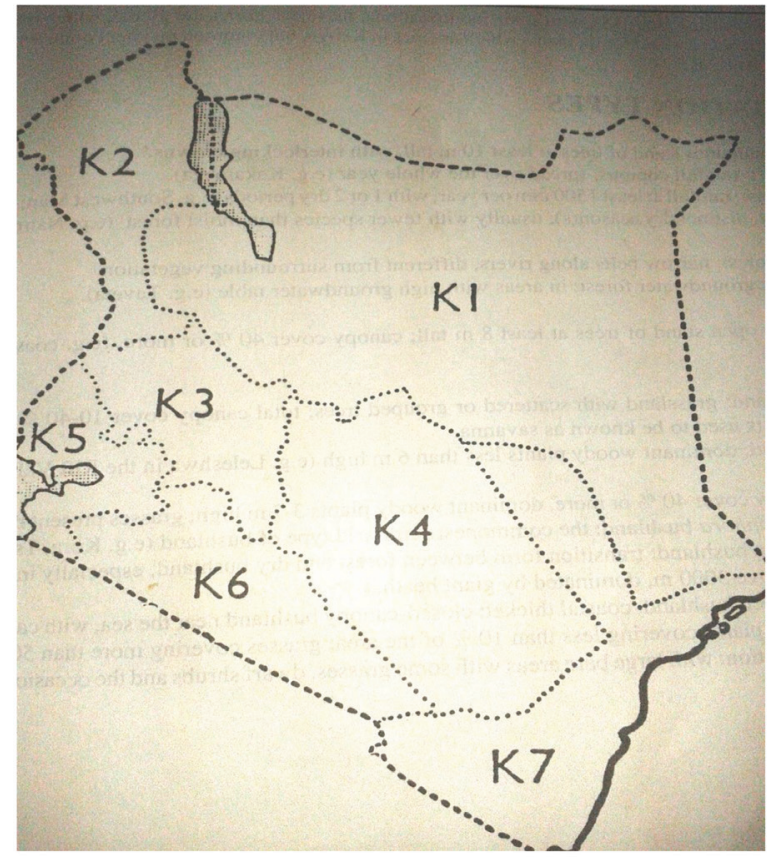

Figure 1: Map of Kenya showing geographical divisions of the Kenyan flora (Sue, Mestin and Inga 1995).

Notes: K-Geographical zoning according to East African flora. K3-Rift valley, K4-Central, K5-Nyanza, K6-Maasai, K7-Coast.

\section{Sampling Design}

Samples used in the study were collected by purposive random sampling technique. One tree was selected from KUMPRG where two samples, leaf and stem bark were harvested. The other 12 samples consisting of one leaf and one stem bark of each tree (six leaves and six stem barks) were randomly obtained from the six geographical areas as shown in Table 1 and Figure 1. These samples were coded with letters SB, SL and numerical values 1-6 (S-code for reference, B-code for bark, L-code for leaf and 1-6 representing the geographical areas). All samples were identified by a certified botanist, Mr. Karimi of Kenyatta University and voucher specimens (MO/002-008/2013) deposited in the East African Herbarium at the National Museums of Kenya, Nairobi.

\section{Sample Harvesting and Processing}

All samples were processed using WHO guidelines for good agricultural and collection practices for medicinal plants (WHO 2003). Leaves were cleaned and rinsed while the outer cork was removed from the stem bark before being dried under shade. After drying for two weeks, the samples were ground and packaged in $50 \mathrm{~g}, 100 \mathrm{~g}$ and $400 \mathrm{~g}$ airtight plastic containers, coded then stored at room temperature $\left(25^{\circ} \mathrm{C}\right)$ for subsequent work. Precautions to minimise contamination both during harvesting, processing and storage were taken (WHO 2003). 


\section{GC-MS METHOD DEVELOPMENT}

\section{Sample preparation}

Approximately $0.04 \mathrm{~g}$ ethyl acetate extract was accurately weighed and reconstituted with $4 \mathrm{~mL}$ of high-performance liquid chromatography (HPLC) grade ethyl acetate and filtered.

\section{Determination of chromatographic parameters}

A GC-MS hyphenated system used during method development and analysis included GCMS Agilent 7890A GC system fitted with Agilent 7000 QQQ mass detector and Agilent 7693 auto sampler (Agilent Technologies Inc., 5301 Stevens Creek Boulevard Santa Clara, CA). The column used was Agilent column type 19091S-433, 525 OC, 30 m length $x$ $0.25 \mathrm{~mm}$ internal diameter $\times 0.25 \mu \mathrm{m}$ film thickness. The other columns used during method development included Ultrainer $30 \mathrm{~m} \times 0.25 \mathrm{~mm} \times 1.40 \mu \mathrm{m}$, and JW $5 \mathrm{~ms} 18 \mathrm{~m} \times 0.18 \mathrm{~mm}$ $x 0.18 \mu \mathrm{m}$. Chromatographic parameters investigated in this study included temperature ranges of between $70^{\circ} \mathrm{C}$ and $300^{\circ} \mathrm{C}$, flow rate of between $0.8 \mathrm{~mL}-2 \mathrm{~mL}$, injection volume of $1 \mu \mathrm{L}$, run time of between $28 \mathrm{~min}$ and $60 \mathrm{~min}$. Different types of capillary columns were tried. The mobile phase was helium gas $(99.999 \%)$ and Mass-hunter software used to check peaks. Identification of components of the GC-MS spectra was done using Wiley Mass Spectral Library database.

\section{Determination of GC-MS fingerprints and data analysis}

A GC-MS chromatogram with many profiles of separated compounds from $W$. ugandensis was considered a fingerprint. Analysis of the fingerprint was done by visual comparison of retention data, and the tentative structural identity of each compound based on mass spectra as proposed by several studies (Hendriks et al. 2005; Alaerts et al. 2010, 2012; Tistaert, Dejaegher and Vander 2011; Zou, Duai and Zhang 2012). The percentage of each compound in the extract was determined using percentage of peak area, calculated as area under curve of each peak divided by the total of all areas under curve.

In similarity analysis, the entire fingerprint including individual compounds their relative retention time and relative peak areas was considered with slight modifications as proposed by (Alaerts et al. 2010, 2012; Tistaert, Dejaegher and Vander 2011). In addition, reference samples should be included for quality evaluation purposes during similarity analysis. Because standards were not available, a reference sample was prepared and used for similarity analysis during evaluation of samples from other geographical zones in Kenya. From the reference sample, a fingerprint was compiled and the similarity of individual chromatograms determined against the compiled chromatogram for quality control as suggested by Alaerts et al. (2010; 2012) and, Tistaert, Dejaegher and Vander (2011). 


\section{RESULTS AND DISCUSSION}

\section{Method Development and Chromatographic Fingerprints of the Reference Leaf and Stem Bark}

Based on the previous thin-layer chromatography (TLC) and HPLC methods developed in this study (Onyambu 2016), an ethyl acetate extract was chosen for GC-MS method development. The ethyl acetate extract run with a DB-5ms capillary column with helium gas mobile phase for 50 min showed 12 major peaks. Moreover, a change of column with different film thickness (ultrainner $30 \mathrm{M} \times 0.25 \mathrm{~mm}, 1.40 \mu \mathrm{m}$ film thickness) showed five major picks. The two columns therefore did not show a separation of as many components which may serve as fingerprints representing the constituents in $W$. ugandensis. However, a change of column with different stationary phase (Agilent 19091S-30 m x $0.25 \mathrm{~mm} \times 0.25 \mu \mathrm{m}$ ) showed over 100 peaks for the stem-bark and leaf. This column was therefore considered suitable for the GC-MS fingerprinting method in this study. Several chromatographic parameters were studied including columns, temperature, mobile phases and flow rate among others. As shown in Table 2, the best GC-MS method conditions determined for running W.ugandensis stem bark and leaf extracts included an Agilent $19091 \mathrm{~S}-30 \mathrm{~m} \mathrm{x}$ $0.25 \mathrm{~mm} \times 0.25 \mu \mathrm{m}$ capillary column, a sample injection volume of $1 \mu \mathrm{L}$, splitless mode, flow rate of $1.2 \mathrm{~mL} / \mathrm{min}$, temperature $110^{\circ} \mathrm{C}-200^{\circ} \mathrm{C}$ at $10^{\circ} \mathrm{C}$ held for $1 \mathrm{~min}, 200^{\circ} \mathrm{C}-280^{\circ} \mathrm{C}$ at $5^{\circ} \mathrm{C} /$ min held for $9 \mathrm{~min}$, inlet temperature of $250^{\circ} \mathrm{C}$ and post run temperature of $85^{\circ} \mathrm{C}$ for $2 \mathrm{~min}$. The run time was $40 \mathrm{~min}$ and scan range of $35 \mathrm{mmu}-500 \mathrm{mmu}$.

Table 2: Conditions for GC-MS optimum method.

\begin{tabular}{lll}
\hline GC-MS system & Parameter & Conditions \\
\hline Auto sampler & Injection volume & $1 \mu \mathrm{L}$ \\
& Solvent washes & 3 \\
& (1) pre-injection & 3 \\
& (2) post-injection & \\
& Sample washes & 2 \\
& Sample pump & 2 \\
Inlet & Plunger speed & Fast \\
& Heater & $250^{\circ} \mathrm{C}$ \\
& Pressure & $93.427 \mathrm{kPa}$ \\
Septum purge flow & $3 \mathrm{~mL} / \mathrm{min}$ \\
& Injection mode & Splitles \\
& Flow & $1.2 \mathrm{~mL} / \mathrm{min}$ \\
& Velocity & $41.026 \mathrm{~cm} / \mathrm{sec}$ \\
& Hold up time & 1.2187 \\
& Initial temp & $110^{\circ} \mathrm{C}$ \\
& Ramp 1 & $110^{\circ} \mathrm{C}-200^{\circ} \mathrm{C} @ 10^{\circ} \mathrm{C} / \mathrm{min} ;$ Held $1 \mathrm{~min}$ \\
& Ramp 2 & $200^{\circ} \mathrm{C}-280^{\circ} \mathrm{C} @ 5^{\circ} \mathrm{C} / \mathrm{min} ;$ Held 9 min \\
& Post run & $85^{\circ} \mathrm{C} \mathrm{for} 2 \mathrm{~min}$ \\
\hline
\end{tabular}

Malay J Pharm Sci, Vol. 19, No. 2 (2021): 23-46 
Table 2: (continued)

\begin{tabular}{lll}
\hline GC-MS system & Parameter & Conditions \\
\hline MS & lon source & EI \\
& Source temperature & $250^{\circ} \mathrm{C}$ \\
& Run time & $40 \mathrm{~min}$ \\
& Scan range & $35-500 \mathrm{mmu}$ \\
\hline
\end{tabular}

The GC-MS method showed several components in the stem bark used as reference material during method development. According to Wiley library search results, over 100 compounds in the ethyl acetate extract of $W$. ugandensis stem bark were tentatively identified. The match factor of the mass spectra for all the components was more than 50. However, 22 compounds were tentatively identified and discussed. Table 3 shows the retention time $\left(t_{R}\right)$, tentative identity and chromatographic area percent derived from GC-MS for the selected compounds. These parameters formed the key components for fingerprinting in the study (Hendriks et al. 2005; Alaerts et al. 2010, 2012; Tistaert, Dejaegher and Vander 2011; Zou, Duai and Zhang 2012). Figure 2 shows the gas chromatogram for this separation. The compounds chosen had an area percent of above 0.3, they are common in plants and their pharmaceutical and/or medicinal value is known. They included alpha-cubebene, (+)-epi-bicyclosesquiphellandrene, cubedol, phenol, 3,5-bis(1,1-dimethylethyl), humulane1,6-dien-3-ol, isopropyl myristate, 4-camphenylbutan-2-one, alloaromadendren, delta4androstene-3beta17beta-diol, 2-methoxy phenol and longifolenaldehyde. The major volatile components are sesquiterpenes and some plant sterols ( $\left.t_{R} 6.3-33.2\right)$. Nerolidol $2(0.9 \%)$, beta-guaiene $(1.7 \%)$, isolongifolene 9-hydroxy $(1.8 \%)$, corymbolone $(0.7 \%)$, arteannuin b $(0.7 \%)$, squalene $(0.8 \%)$ and gamma-sitosterol $(2.2 \%)$ were the most abundant compounds in the chromatograms and their individual peak area was more than $8 \%$ of the total area of all peaks.

Table 3: Components tentatively identified in $W$. ugandensis reference stem bark (SB).

\begin{tabular}{lllllll}
\hline $\begin{array}{l}\text { Peak } \\
\text { no. }\end{array}$ & $\mathbf{t}_{\boldsymbol{R}}$ & Tentative identity & $\begin{array}{l}\text { Molecular } \\
\text { formula }\end{array}$ & Mass & $\begin{array}{l}\text { Area } \\
\%\end{array}$ & $\begin{array}{l}\text { Match } \\
\text { factor }\end{array}$ \\
\hline 1 & 6.3 & Alpha-cubebene & $\mathrm{C}_{15} \mathrm{H}_{24}$ & 204.2 & 0.4 & 93.0 \\
2 & 6.5 & (+)-epi-Bicyclosesquiphellandrene; & $\mathrm{C}_{15} \mathrm{H}_{24}$ & 204.2 & 0.3 & 85.5 \\
3 & 7.8 & Cubedol & $\mathrm{C}_{15} \mathrm{H}_{26} \mathrm{O}$ & 222.2 & 0.3 & 83.0 \\
4 & 7.9 & Phenol,3,5-bis(1,1-dimethylethyl) & $\mathrm{C}_{14} \mathrm{H}_{22} \mathrm{O}$ & 206.2 & 0.4 & 79.3 \\
5 & 8.1 & Beta-bisabolene & $\mathrm{C}_{15} \mathrm{H}_{24}$ & 222.2 & 0.4 & 64.2 \\
6 & 8.5 & Nerolidol 2 & $\mathrm{C}_{15} \mathrm{H}_{26} \mathrm{O}$ & 222.2 & 0.9 & 95.2 \\
7 & 9.1 & Humulane-1,6-dien-3-ol & $\mathrm{C}_{15} \mathrm{H}_{26} \mathrm{O}$ & 222.2 & 0.3 & 82.3 \\
8 & 10.0 & Isolongifolene, 9-hydroxy- & $\mathrm{C}_{15} \mathrm{H}_{24} \mathrm{O}$ & 220.2 & 1.8 & 70.5 \\
9 & 12.3 & 4-Camphenylbutan-2-one & $\mathrm{C}_{14} \mathrm{H}_{22} \mathrm{O}$ & 206.2 & 0.6 & 82.7 \\
10 & 12.7 & Alloaromadendrene & $\mathrm{C}_{15} \mathrm{H}_{24}$ & 204.2 & 0.3 & 65.1 \\
11 & 13.4 & Corymbolone & $\mathrm{C}_{15} \mathrm{H}_{24} \mathrm{O}_{2}$ & 236.2 & 0.7 & 69.7 \\
12 & 15.0 & Beta-guaiene & $\mathrm{C}_{15} \mathrm{H}_{24}$ & 204.2 & 1.7 & 82.9 \\
\hline & & & & \multicolumn{2}{c}{ (continued on next page) }
\end{tabular}


Table 3: (continued)

\begin{tabular}{|c|c|c|c|c|c|c|}
\hline $\begin{array}{l}\text { Peak } \\
\text { no. }\end{array}$ & $t_{R}$ & Tentative identity & $\begin{array}{l}\text { Molecular } \\
\text { formula }\end{array}$ & Mass & $\begin{array}{l}\text { Area } \\
\%\end{array}$ & $\begin{array}{l}\text { Match } \\
\text { factor }\end{array}$ \\
\hline 13 & 15.4 & Phenol, 2-methoxy & $\mathrm{C}_{7} \mathrm{H}_{8} \mathrm{O}_{2}$ & 124 & 0.8 & 73.8 \\
\hline 14 & 16.5 & 1-docosene & $\mathrm{C}_{22} \mathrm{H}_{44}$ & 308.8 & 0.8 & 90.3 \\
\hline 15 & 17.3 & $\begin{array}{l}\text { 5-Azulenemethanol, } 1,2,3,4,5,6,7,8- \\
\text { octahydro-alpha,alpha,3,8tetramethyl-, } \\
\text { acetate, [3S (3alpha,5alpha,8alpha)] }\end{array}$ & $\mathrm{C}_{17} \mathrm{H}_{28} \mathrm{O}_{2}$ & 264.2 & 0.3 & 68.6 \\
\hline 16 & 18.5 & Longifolenaldehyde & $\mathrm{C}_{15} \mathrm{H}_{24} \mathrm{O}$ & 220.2 & 0.3 & 76.33 \\
\hline 17 & 19.5 & Arteannuin $b$ & $\mathrm{C}_{15} \mathrm{H}_{20} \mathrm{O}_{3}$ & 248.1 & 0.7 & 59.9 \\
\hline 18 & 19.8 & $\begin{array}{l}\text { Alanine,N-acetyl-3-phenyl-N- } \\
\text { (trifluoroacetyl)-, methyl ester, L- }\end{array}$ & $\mathrm{C}_{14} \mathrm{H}_{14} \mathrm{~F}_{3} \mathrm{NO}_{4}$ & 317 & 0.4 & 50.78 \\
\hline 19 & 22.1 & $\begin{array}{l}\text { 3alpha,4beta-Dihydroxy- } \\
\text { 1,5,7alpha(H),6beta(H)-guai- } \\
\text { 10(15),11(13)-dien-6,12-olide }\end{array}$ & $\mathrm{C}_{15} \mathrm{H}_{20} \mathrm{O}_{4}$ & 264 & 0.3 & 53.2 \\
\hline 20 & 22.4 & $\begin{array}{l}\text { 1,3,4,4abeta,5,6,8,9- } \\
\text { Octahydro-4a-hydroxy- } 6,6,8 \mathrm{~b}- \\
\text { trimethylazuleno( } 5,6-\mathrm{c}) \text { furan-3-one }\end{array}$ & $\mathrm{C}_{15} \mathrm{H}_{20} \mathrm{O}_{3}$ & 248.1 & 0.8 & 72.9 \\
\hline 21 & 28.8 & Squalene & $\mathrm{C}_{30} \mathrm{H}_{50}$ & 410.4 & 0.8 & 65.3 \\
\hline 22 & 33.2 & Gamma-sitosterol & $\mathrm{C}_{29} \mathrm{H}_{50} \mathrm{O}$ & 414.4 & 2.2 & 91.1 \\
\hline
\end{tabular}

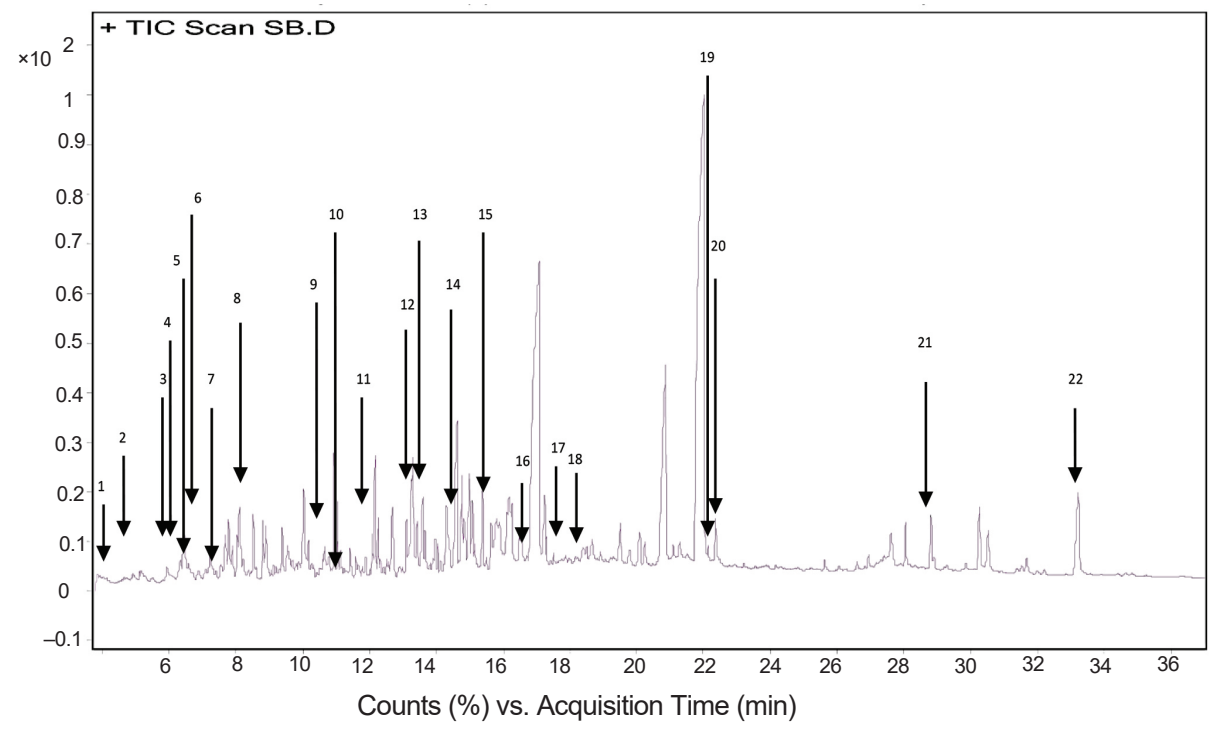

Figure 2: Gas chromatogram of the reference stem-bark.

Notes: Numbers 1-22 represent peaks with area percent of above 0.3 selected as fingerprint for $W$. ugandensis reference stem-bark (SB) 
Similarly, over 100 compounds were tentatively identified from the ethyl acetate extract of $W$. ugandensis reference leaf. The match factor for all the components was above 55. Table 4 shows 38 compounds chosen based on area percent and known medicinal and/ or pharmaceutical value. The chromatogram with these compounds is shown in Figure 3. The major components seen were sesquiterpenes and plant sterols. They included alpha-cubebene, alfa-copaene, caryophyllene, alpha-calacorene, himachala-2,4-diene, cislanceol, isolongifolene, cis-thujopsene, phenol, nerolidyl acetate, humulane-1,6-dien-3-ol, alpha-bisabolol, alpha-santonin squalene, phytol, phenol 2-methoxy, vitamin E, ergost-5en-3-ol, gamma-sitosterol and phytonadione. The most abundant components included nerolidol $2(1 \%)$, thujopsene-13 (1.1\%), isongifolene 9 hydroxy $(1.2 \%)$, phenol 2 methoxy (2.2\%), vitamin $E(1.1 \%)$ and gamma-sitosterol (3.9\%) which accounted for over $10 \%$ of the total peak area.

Table 4: Components tentatively identified in $W$. ugandensis reference leaf (SL).

\begin{tabular}{|c|c|c|c|c|c|c|}
\hline $\begin{array}{l}\text { Peak } \\
\text { No. }\end{array}$ & $t_{R}$ & Tentative identity & $\begin{array}{l}\text { Molecular } \\
\text { formula }\end{array}$ & Mass & $\begin{array}{l}\text { Area } \\
\%\end{array}$ & $\begin{array}{l}\text { Match } \\
\text { factor }\end{array}$ \\
\hline 1 & 5.9 & Alpha-cubebene & $\mathrm{C}_{15} \mathrm{H}_{24}$ & 204.2 & 0.1 & 67.7 \\
\hline 2 & 6.3 & Alfa-copaene & $\mathrm{C}_{15} \mathrm{H}_{24}$ & 204.2 & 0.2 & 76.8 \\
\hline 3 & 6.9 & Caryophyllene & $\mathrm{C}_{15} \mathrm{H}_{24}$ & 204.2 & 0.4 & 80.6 \\
\hline 4 & 7.1 & Oxalic acid, 2-ethylhexyl ethyl ester & $\mathrm{C} 12 \mathrm{H} 22 \mathrm{O} 4$ & 230.2 & 0.2 & 60.5 \\
\hline 5 & 8.5 & Nerolidol 2 & $\mathrm{C} 15 \mathrm{H} 26 \mathrm{O}$ & 222.2 & 1.0 & 86.9 \\
\hline 6 & 8.6 & Alpha-calacorene & $\mathrm{C} 15 \mathrm{H} 20$ & 200.2 & 0.1 & 57.9 \\
\hline 7 & 9.1 & Thujopsene-I3 & $\mathrm{C}_{15} \mathrm{H}_{24}$ & 204.2 & 1.1 & 82.3 \\
\hline 8 & 9.4 & Himachala-2,4-diene & $\mathrm{C}_{15} \mathrm{H}_{24}$ & 204.2 & 0.5 & 83.3 \\
\hline 9 & 9.9 & Cis-lanceol & $\mathrm{C}_{15} \mathrm{H}_{24} \mathrm{O}$ & 220.2 & 0.3 & 78.9 \\
\hline 10 & 10.0 & Isolongifolene, 9-hydroxy & $\mathrm{C}_{15} \mathrm{H}_{24} \mathrm{O}$ & 220.2 & 1.2 & 66.6 \\
\hline 11 & 10.1 & $\begin{array}{l}\text { 1,4-Methanoazulene-9-methanol, } \\
\text { decahydro-4,8,8-trimethyl-, } \\
\text { [1S-(1alpha,3abeta,4alpha,8abeta,9R*)] }\end{array}$ & $\mathrm{C}_{15} \mathrm{H}_{26} \mathrm{O}$ & 222.2 & 2.3 & 85.3 \\
\hline 12 & 10.3 & Farnesol isomer a & $\mathrm{C}_{15} \mathrm{H}_{26} \mathrm{O}$ & 222.2 & 0.3 & 79.3 \\
\hline 13 & 10.7 & cis-thujopsene & $\mathrm{C}_{15} \mathrm{H}_{24}$ & 204.2 & 0.8 & 76.1 \\
\hline 14 & 11.1 & Phenol, 2-methoxy & $\mathrm{C}_{7} \mathrm{H}_{8} \mathrm{O}_{2}$ & 124 & 0.8 & 71.6 \\
\hline 15 & 11.8 & Nerolidyl acetate & $\mathrm{C}_{17} \mathrm{H}_{28} \mathrm{O}_{2}$ & 264.2 & 0.2 & 60.0 \\
\hline 16 & 12.3 & Humulane-1,6-dien-3-ol & $\mathrm{C}_{15} \mathrm{H}_{26} \mathrm{O}$ & 222.2 & 0.7 & 81.8 \\
\hline 17 & 12.5 & Alpha-bisabolol & $\mathrm{C}_{15} \mathrm{H}_{26} \mathrm{O}$ & 222.2 & 0.4 & 64.2 \\
\hline 18 & 12.7 & Alpha-santonin & $\mathrm{C}_{15} \mathrm{H}_{18} \mathrm{O}_{3}$ & 246.1 & 0.1 & 58.5 \\
\hline 19 & 13.2 & $\begin{array}{l}\text { (5a,alpha,9a,beta,9b,beta)- } \\
5,5 a, 6,7,8,9,9 a, 9 b-o c t a h y d r o-6,6,9 a- \\
\text { trimethylnaphtho[1,2-c]furan-1-(3H)-one } \\
\text { (drimenin) }\end{array}$ & $\mathrm{C}_{15} \mathrm{H}_{22} \mathrm{O}_{2}$ & 234.2 & 0.8 & 76.4 \\
\hline 20 & 13.5 & Berkheyaradulene & $\mathrm{C}_{15} \mathrm{H}_{24}$ & 204.2 & 0.3 & 62.7 \\
\hline
\end{tabular}


Table 4: (continued)

\begin{tabular}{lllllll}
\hline $\begin{array}{l}\text { Peak } \\
\text { No. }\end{array}$ & $\mathbf{t}_{\boldsymbol{R}}$ & Tentative identity & $\begin{array}{l}\text { Molecular } \\
\text { formula }\end{array}$ & Mass & $\begin{array}{l}\text { Area } \\
\%\end{array}$ & $\begin{array}{l}\text { Match } \\
\text { factor }\end{array}$ \\
\hline 21 & 13.6 & 9-Eicosene, (E) & $\mathrm{C}_{20} \mathrm{H}_{40}$ & 280.3 & 0.7 & 90.2 \\
22 & 13.7 & Squalene & $\mathrm{C}_{30} \mathrm{H}_{50}$ & 410.4 & 0.3 & 70.2 \\
23 & 15.0 & Sebacic acid, digeranyl ester & $\mathrm{C}_{30} \mathrm{H}_{50} \mathrm{O}_{4}$ & 474.4 & 0.1 & 53.3 \\
24 & 15.3 & Phytol & $\mathrm{C}_{20} \mathrm{H}_{40} \mathrm{O}$ & 296 & 0.7 & 80.7 \\
25 & 15.4 & Phenol, 2-methoxy- & $\mathrm{C}_{7} \mathrm{H}_{8} \mathrm{O}_{2}$ & 124.1 & 2.2 & 76.0 \\
26 & 16.4 & Phenol, 4,4'-(1-methylethylidene)bis & $\mathrm{C}_{15} \mathrm{H}_{16} \mathrm{O}_{2}$ & 228.1 & 0.1 & 64.0 \\
27 & 18.9 & Pyrimidine-2,4,6-trione, 1-butyl-5-[(2- & $\mathrm{C}_{15} \mathrm{H}_{25} \mathrm{~N}_{5} \mathrm{O}_{3}$ & 323.2 & 0.1 & 56.0 \\
& & piperazin-1-yl-ethylamino)methylene]- & & & & \\
28 & 19.4 & 1-Docosene & $\mathrm{C}_{22} \mathrm{H}_{44}$ & 308.3 & 0.6 & 88.6 \\
29 & 22.4 & 3-Eicosene, (E) & $\mathrm{C}_{20} \mathrm{H}_{40}$ & 280.3 & 0.3 & 75.6 \\
30 & 25.7 & Squalene & $\mathrm{C}_{30} \mathrm{H}_{50}$ & 410.4 & 0.2 & 61.6 \\
31 & 28.4 & 1,2-Dihydroharmaline & $\mathrm{C}_{12} \mathrm{H}_{14} \mathrm{~N}_{2} \mathrm{O}$ & 202.1 & 0.3 & 61.9 \\
32 & 28.6 & Gamma-tocopherol & $\mathrm{C}_{28} \mathrm{H}_{48} \mathrm{O}_{2}$ & 416.4 & 0.4 & 86.2 \\
33 & 28.9 & Geranyl-alpha-terpinene & $\mathrm{C}_{20} \mathrm{H}_{32}$ & 272.3 & 0.3 & 58.5 \\
34 & 29.9 & Vitamin E & $\mathrm{C}_{29} \mathrm{H}_{50} \mathrm{O}_{2}$ & 430.4 & 1.1 & 89.4 \\
35 & 31.4 & Ergost-5-en-3-ol, (3,beta) & $\mathrm{C}_{28} \mathrm{H}_{48} \mathrm{O}$ & 400.4 & 0.1 & 60.4 \\
36 & 33.2 & Gamma-sitosterol & $\mathrm{C}_{29} \mathrm{H}_{50} \mathrm{O}$ & 414.4 & 3.9 & 85.6 \\
37 & 33.7 & Phytonadione & $\mathrm{C}_{31} \mathrm{H}_{46} \mathrm{O}_{2}$ & 450.4 & 0.1 & 59.3 \\
38 & 34.8 & 9,19-Cycloergost- 24(28)-en-3-ol, 4,14- & $\mathrm{C}_{30} \mathrm{H}_{50} \mathrm{O}$ & 426 & 0.3 & 77.8 \\
& & dimethyl-, (3beta,4alpha,5alpha.) & & & & \\
\hline
\end{tabular}




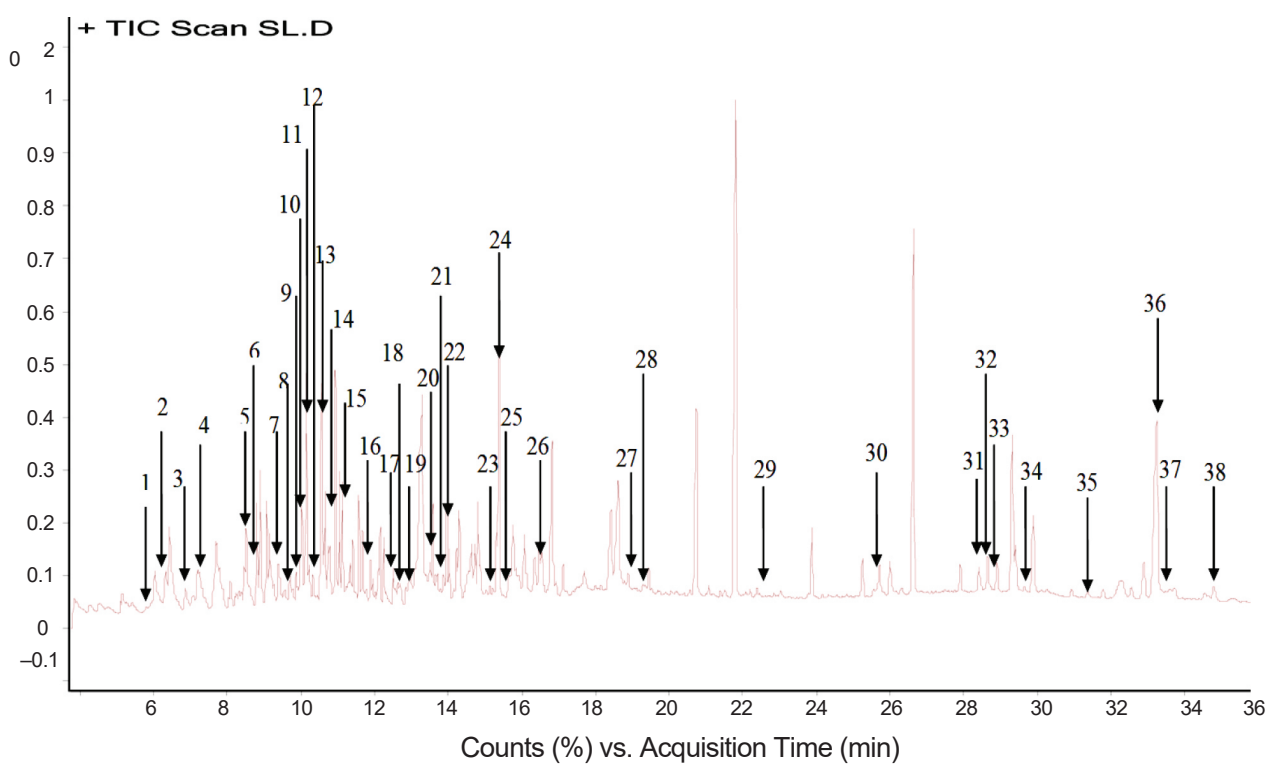

Figure 3: Gas chromatogram of reference leaf.

Notes: Numbers 1-38 represent peaks with area percent of above

0.3 selected as fingerprint for $W$. ugandensis reference leaf (SL)

The results revealed that $W$. ugandensis leaves have more components than the stem bark and the two parts share some similar components such as alpha-cubebene, humulene, squalene and gamma-sitosterol among others.

The results of GC-MS method in this study further agree with previous studies on $W$. ugandensis which concluded that the plant has many phyto-constituents which are sesquiterpenoids (Kioy, Gray and Waterman 1990; Mashimbye, Maumela and Drewes 1999; Drage et al. 2014). This is because many of the compounds separated and identified in both the leaf and stem bark were sesquiterpenes. Moreover, most of the components separated and identified in this study are of good therapeutic value and have been reported before but not in $W$. ugandensis. For instance, Copaene is a tri-cyclic sesquiterpene present in essential oils of medicinal and aromatic plants (Husan, Bsak and Abdulgani 2014). The cytotoxic and cytogenic effects of copaene on rat neurone and neuroblastoma cell lines has been studied and reported by the same author. Hamulene, phenol, eudesma, beta and alpha tocopherol, caryophyllene and caryophyllene oxide are also plant sesquiterpenes with pronounced anti-inflammatory, antimicrobial antitumor and antioxidant properties (Alexandre et al. 2009; Venkata et al. 2012). Nerelidol is a sesquiterpene previously found in tea, lavender, jasmine and ginger. It is a component in many essential oils. It has been studied and said to have antifungal and anti-malarial, antileishmanial properties and good effect for insomnia, pain and skin conditions (National Center for Biotechnology Information 2020).

Squalene has anti-artherosclerotic properties and plays a role in skin anti-aging while gamma tocopherol is anti-inflammatory (Venkata et al. 2012; Jianq et al. 2001). Betaguaiene is used in fragrance and flavoring industries for spicy aromas and taste while isolongifolene has antioxidant and radical scavenging properties (Kowalya and Elangovan 2013). Arteannuin b which was identified in the stem bark has been studied and converted 
to artemisinin the potent antimalarial principle in Artemisia annua (Nair and Basike 1993). Vitamin $\mathrm{E}$ seen in both leaf and stem bark has antioxidant, anticancer and lowers risk of heart diseases. It has been isolated before from asparagus, corns and spinach and is found in other green leafy vegetables. Corymbolene is a compound with antiplasmodial activity and has been characterised in Kenyan plants (Muthaura et al. 2011). However, like many compounds in this study, it is the first time it is being reported in W. ugandensis. Gammasitosterol is a phytosterol present in many plants used in traditional medicines and has very strong antifungal and antibacterial properties. It has been used to treat ulcers, bronchitis, diabetes and heart diseases (Venkata et al. 2012). This compound formed substantial amount of constituents in both leaf and stem-bark of $W$. ugandensis in the present study and it is being reported for the first time in this plant.

Based on the components characterised in both the leaf and stem bark, this study corroborates with previous studies which reported the anti-malarial (Muthaura, Rukunga and Chhabra 2007), antimicobacterial (Wube and Bucar 2005), antimicrobial and cytotoxic (Mbwambo and Erasto 2009; Lacroix et al. 2011), antifungal (Olila and Olwa 2001) and invitro antileishmanial activity (Ngure and Tonui 2009) for W. ugandensis.

The compounds identified in both leaf and stem bark can form fingerprints for quality evaluation especially in confirming authenticity and purity of products in the market as suggested by Zou, Duai and Zhang (2012). WHO (2002) recommends the use of GCMS fingerprints for standardisation and quality control of both raw materials and finished products. The method developed in this study is fast, simple to use and has a short run time. This is because most of the compounds are eluted within $36 \mathrm{~min}$. In addition, the sample preparation mechanisms were not complicated as it involved extraction and filtration with $0.45 \mu \mathrm{m}$ micro filters. The method can therefore be used for routine analysis of $W$. ugandensis based herbal materials. The profile of the test material should be compared to the one for an authentic material and conclusions on quality made based on consistency.

\section{Use of GC-MS Fingerprinting Method to Evaluate Similarity of W. ugandensis from Different Geographical Zones}

The use of GC-MS method developed in this study further revealed the chemical profiles of $W$. ugandensis from different geographical zones in Kenya. They all had over 100 compounds. However, compounds known to have pharmaceutical and/or medicinal value were selected and reported. Table 5 shows the components in stem bark from six geographical zones and the area percent for each. There were differences in the number of components present in each sample. Whereas 12 components were tentatively identified in 1B, samples $2 \mathrm{~B}, 3 \mathrm{~B}, 4 \mathrm{~B}, 5 \mathrm{~B}$, and $6 \mathrm{~B}$ had $23,20,28,23$ and 31 components, respectively. The study further observed that some components were present in all the samples from the various zones while others were only present in two or three samples. There were other compounds present that were unique to some samples. For example, alpha-cubebene $\left(t_{R} 6.3\right)$ was in all samples except $2 B$ and $5 B$, while nerolidol $2(8.5)$ was present in all samples. Isolongifolene (10.0) and squalene (28.8) were in all samples except 3B, while 2- methoxy phenol (15.4) was in all except 1B. Gamma-sitosterol (33.2) was also in all samples except $2 \mathrm{~B}$.

Malay J Pharm Sci, Vol. 19, No. 2 (2021): 23-46 
Table 5: Compounds tentatively identified in W. ugandensis stem bark from different geographical zones.

\begin{tabular}{|c|c|c|c|c|c|c|c|c|}
\hline \multirow[t]{3}{*}{$t_{R}$} & \multirow[t]{3}{*}{ Potential identity } & \multicolumn{7}{|c|}{ Area (\%) } \\
\hline & & \multicolumn{3}{|c|}{ Reference } & \multicolumn{4}{|c|}{ Samples } \\
\hline & & SB & 1B & 2B & 3B & 4B & 5B & 6B \\
\hline 6.3 & Alpha-cubebene & 0.4 & 0.1 & - & 0.3 & 0.2 & - & 0.9 \\
\hline 6.5 & (+)-epi-Bicyclosesquiphellandrene & 0.3 & 0.1 & - & - & - & - & 0.6 \\
\hline 6.9 & Caryophyllene & - & - & - & 0.3 & 3.7 & 0.5 & 2.2 \\
\hline 7.2 & Beta-bisabolene & - & - & 0.3 & - & - & - & 2.4 \\
\hline 7.4 & Isoledene & - & - & - & - & - & - & 0.1 \\
\hline 7.5 & Copaene & - & - & - & - & 0.1 & - & - \\
\hline 7.5 & Gamma-muurolene & - & - & - & - & - & - & 0.5 \\
\hline 7.8 & Cubedol & 1.0 & 0.6 & - & - & 0.2 & - & 1.6 \\
\hline 7.9 & Phenol,3,5-bis(1,1-dimethylethyl) & 0.4 & 0.4 & 0.1 & 0.1 & 0.2 & - & - \\
\hline 8.0 & Selina-3,7(11)-diene & - & - & 0.1 & - & - & - & - \\
\hline 8.4, & Alpha-calacorene & - & 0.1 & - & - & - & - & 0.2 \\
\hline 8.5 & Nerolidol 2 & 0.9 & 0.3 & 1.5 & 0.7 & 1.1 & 1.2 & 1.2 \\
\hline 9.1 & Humulane & 0.3 & - & 1.6 & - & - & - & - \\
\hline 9.2 & D-Fenchone & - & - & 0.1 & - & - & - & - \\
\hline 9.4 & Longifolenaldehyde & - & - & - & - & - & - & 0.7 \\
\hline 9.6 & Llpha-bisabolol & - & - & 0.2 & - & - & - & - \\
\hline 9.9 & Lanceol, cis & - & - & - & 0.4 & - & 0.4 & - \\
\hline 9.9 & Longipinane, (E) & - & - & - & - & - & 0.3 & - \\
\hline 9.9 & Alpha-guaiene & - & - & - & - & - & 0.1 & - \\
\hline 10.0 & Isolongifolene, 9-hydroxy & 1.8 & 2.8 & 1.2 & - & 1.2 & 1.4 & 1.7 \\
\hline 10.1 & Alpha-santalol & - & 0.2 & 0.2 & - & - & - & - \\
\hline 10.5 & Nerolidol 1 & - & - & - & - & - & - & 0.2 \\
\hline 10.6 & Isocaryophillene & - & - & 0.4 & - & - & - & - \\
\hline 11.7 & Bergamotol, Z-alpha-trans & - & - & 0.7 & - & - & 0.2 & 0.2 \\
\hline 11.8 & $\begin{array}{l}\text { Anthracene, } \\
1,2,3,4,5,6,7,8-o c t a h y d r o-9,10- \\
\text { dimethyl }\end{array}$ & - & - & 0.1 & 0.2 & 0.3 & - & - \\
\hline 12.2 & Thujopsene-I3 & - & - & - & - & - & 0.3 & 1.0 \\
\hline 12.3 & 4-Camphenylbutan-2-one & 0.6 & - & - & - & - & - & - \\
\hline 12.7 & Alloaromadendrene & 0.3 & - & - & - & - & - & - \\
\hline 12.8 & Caryophyllene-(I1) & - & - & 0.4 & - & 3.2 & - & 1.1 \\
\hline 13.4 & Corymbolone & 0.7 & - & - & - & - & - & - \\
\hline 15.0 & Beta-guaiene & 1.7 & 0.6 & - & - & - & 0.1 & - \\
\hline
\end{tabular}


Table 5: (continued)

\begin{tabular}{|c|c|c|c|c|c|c|c|c|}
\hline \multirow[t]{3}{*}{$t_{R}$} & \multirow[t]{3}{*}{ Potential identity } & \multicolumn{7}{|c|}{ Area $(\%)$} \\
\hline & & \multicolumn{3}{|c|}{ Reference } & \multicolumn{4}{|c|}{ Samples } \\
\hline & & SB & 1B & 2B & 3B & 4B & 5B & $6 B$ \\
\hline 15.3 & Quinoxaline 2 isopropyl-1,4 diol & - & - & 2.2 & - & 1.3 & - & - \\
\hline 15.3 & Phytol & - & - & - & 0.5 & 0.2 & - & - \\
\hline 15.4 & 2-Methoxy phenol, & 0.8 & - & 1.8 & 1.2 & 1.6 & 1.6 & 1.5 \\
\hline 15.8 & Eudesma-5,11(13)-dien-8,12-olide & - & - & 0.9 & 0.1 & - & - & - \\
\hline 16.6 & Sclaral (sclareolidelactol) & - & - & - & - & 2.8 & - & 0.2 \\
\hline 17.3 & $\begin{array}{l}\text { 5-Azulenemethanol, } \\
\text { 1,2,3,4,5,6,7,8-octahydro- } \\
\text { alpha,alpha,3,8- } \\
\text { tetramethyl-, acetate, [3S-(3. } \\
\text { alpha,5alpha,8alpha)] }\end{array}$ & 0.3 & 0.3 & - & - & - & - & - \\
\hline 17.6 & Delta-selinene & - & - & - & - & 1.7 & - & - \\
\hline 17.7 & Glycerol 1-palmitate & - & - & - & - & - & 0.8 & - \\
\hline 18.0 & $\begin{array}{l}\text { 3,4-Dihydrocoumarin, } \\
\text { 4,4,5,7,8-pentamethyl-6-cyano }\end{array}$ & - & - & - & 0.1 & - & - & - \\
\hline 18.5 & Longifolenaldehyde & 0.3 & - & - & - & - & - & - \\
\hline 18.7 & Aristolene epoxide & - & - & - & - & 0.4 & - & - \\
\hline 19.5 & Arteannuin b & 0.7 & - & - & - & - & - & - \\
\hline 19.6 & Eudesma-5,11(13)-dien-8,12-olide & - & - & 0.1 & 0.2 & - & - & - \\
\hline 19.7 & Neoclovene oxide & - & - & - & - & - & 3.5 & - \\
\hline 19.8 & $\begin{array}{l}\text { Alanine, N-acetyl-3-phenyl-N- } \\
\text { (trifluoroacetyl)-, methyl ester }\end{array}$ & 0.4 & - & 0.7 & 0.4 & 0.6 & - & 0.1 \\
\hline 20.6 & Murolan-3,9(11)-diene-10-peroxy & - & - & 0.2 & - & - & - & - \\
\hline 22.1 & $\begin{array}{l}\text { 3alpha,4beta.-Dihydroxy- } \\
\text { 1,5,7alpha(H),6beta(H)-guai- } \\
\text { 10(15),11(13)-dien-6,12-olide }\end{array}$ & 0.3 & - & - & - & - & - & - \\
\hline 22.4 & $\begin{array}{l}1,3,4,4 \text { abeta, } 5,6,8,9- \\
\text { Octahydro-4a-hydroxy- } 6,6,8 \mathrm{~b}- \\
\text { trimethylazuleno(5,6-c)furan-3-one }\end{array}$ & 0.8 & 0.4 & - & 0.9 & - & 0.3 & - \\
\hline 22.4 & 5-Eicosene & - & - & - & - & - & - & 0.5 \\
\hline 25.1 & Farnesol isomer a & - & - & - & - & - & 0.3 & 0.5 \\
\hline 26.9 & Trans-geranylgeraniol & - & - & 0.1 & - & 0.4 & 0.2 & 0.6 \\
\hline 28.8 & Squalene & 0.8 & 0.2 & 4.6 & - & 0.2 & 1.7 & 1.1 \\
\hline 29.9 & Vitamin $\mathrm{E}$ & - & - & 0.1 & 0.2 & 0.1 & - & - \\
\hline 29.9 & Alpha-tocopherol & - & 0.1 & - & - & - & - & 0.1 \\
\hline 31.4 & Ergost-5-en-3-ol, (3beta) & - & 0.1 & - & 0.2 & 0.1 & - & 0.1 \\
\hline 32.0 & Stigmasterol & - & - & - & - & - & - & 0.2 \\
\hline
\end{tabular}

Malay J Pharm Sci, Vol. 19, No. 2 (2021): 23-46 
Table 5: (continued)

\begin{tabular}{|c|c|c|c|c|c|c|c|c|}
\hline \multirow[t]{3}{*}{$t_{R}$} & \multirow[t]{3}{*}{ Potential identity } & \multicolumn{7}{|c|}{ Area (\%) } \\
\hline & & \multicolumn{3}{|c|}{ Reference } & \multicolumn{4}{|c|}{ Samples } \\
\hline & & SB & $1 \mathrm{~B}$ & 2B & 3B & 4B & $5 B$ & $6 B$ \\
\hline 33.2 & $\begin{array}{l}\text { Cholest-7-en-3-ol- 15-one, } \\
\text { 14-methyl }\end{array}$ & - & - & - & - & - & - & - \\
\hline 33.2 & Gamma-sitosterol & 2.2 & 2.5 & - & 2.1 & 1.5 & 1.0 & 2.2 \\
\hline 33.4 & Stigmastanol & - & - & - & 5.4 & - & - & 0.2 \\
\hline 34.7 & Stigmast-5-en-3-ol, oleate & - & 0.1 & - & - & 0.2 & 0.2 & - \\
\hline 34.8 & $\begin{array}{l}\text { 9,19-Cyclo-9beta- lanostane- } \\
\text { 3beta,25-diol }\end{array}$ & - & - & - & - & - & 0.2 & - \\
\hline 36.4 & Stigmast-4-en-3-one & - & - & - & - & 0.1 & 0.2 & - \\
\hline
\end{tabular}

Notes: SB-reference sample, B-bark, 1-6 numerical representation of samples obtained from various geographical locations indicated in Table 1.

The study observed that similar components were available in $W$. ugandensis stem bark samples from different geographical zones but their proportions varied. For example, the area percent of nerolidol 2 ranged from $0.3 \%-1.5 \%$. Sample 2B from Trans Mara had the highest amounts at $1.5 \%$ and sample $1 \mathrm{~B}$ from Mombasa having lowest at $0.3 \%$. However, samples 5B from Mount Kenya and 6B from Nakuru had equal amounts of nerolidol 2 at $1.2 \%$. The components that were common in all samples but had varying relative proportions of components included isolongifolene, squalene, 2-methoxy phenol, gamma-sitosterol among others. The area percent range of gamma-sitosterol was $1.0 \%-2.5 \%$, squalene $0.2 \%-4.6 \%$, isolongifolene $1.2 \%-2.8 \%$, phenol 2 methoxy $0.8 \%-1.8 \%$ and caryophyllene $0.3 \%-3.7 \%$.

The components identified in each of the samples from the six geographical zones could serve as fingerprints for authentication and purity verification of products whose source is declared. Similarly, the components that appeared common among all the samples and the range of their area percent could serve as a standard for evaluating the quality including confirmation of authenticity in products whose geographical source is not declared. The overlaid chromatograms comparing stem bark and the reference are shown in Figure 4. 


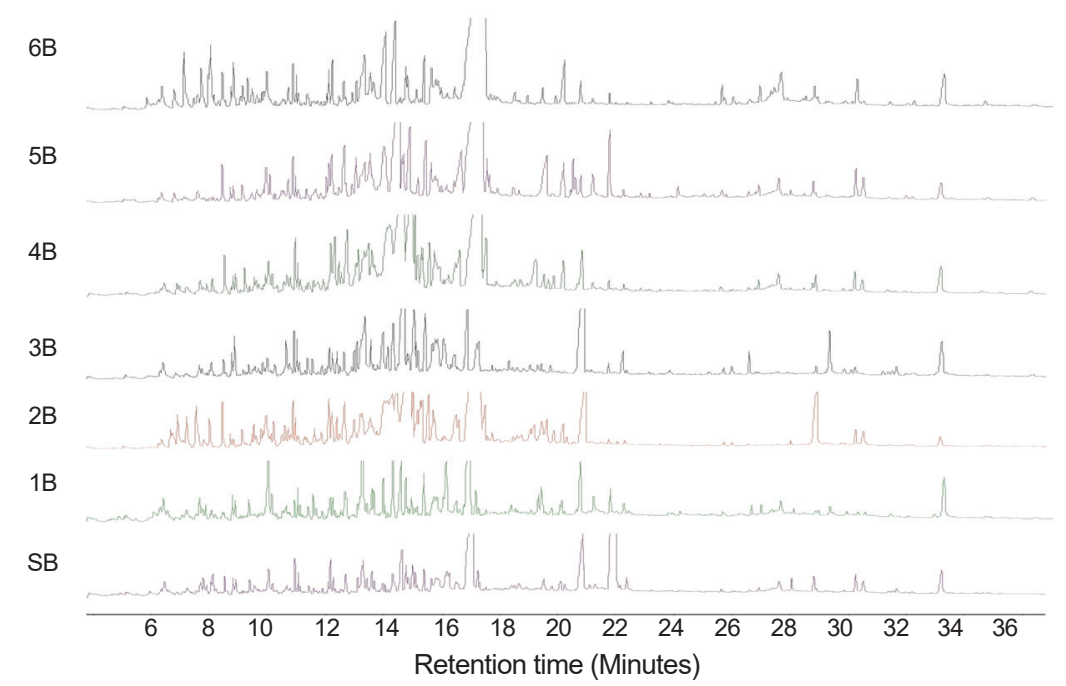

Figure 4: Overlaid gas chromatograms of reference stem-bark and others from six geographical zones.

Notes: SB - Reference, 1B-6B - Stem bark samples from different geographical zones. The overlaid chromatograms show a similarity pattern based on retention time at the horizontal axis thus forming a fingering for identifying W. ugandensis stem-bark based samples.

Table 6 shows the components of leaves from different geographical zones in Kenya. The leaf components varied considerably in both number and specific compounds for the samples. While sample $1 \mathrm{~L}$ had 15 identified components, samples $2 \mathrm{~L}, 3 \mathrm{~L}, 4 \mathrm{~L}, 5 \mathrm{~L}$ and $6 \mathrm{~L}$ had $21,14,20,16$ and 19 components, respectively. The trend observed in the stem bark where some components were common in most samples was also found in the leaf samples. For instance, gamma-tocopherol (28.6) and 2-methoxy phenol (15.4) were present in all leaf samples from six geographical zones. Nerolidol 2 (8.5) and vitamin E (29.9) were present in all samples except 5L; while gamma-sitosterol (33.2) was in all samples except $1 \mathrm{~L}$ and $4 \mathrm{~L}$. Similarly, inspite of the presence in these samples the components differed in proportions as shown by their area percents. Nerolidol 2 ranged from $0.3 \%-1.1 \%$, with phytol ranging from $0.6 \%-1.7 \%$. 2-methoxy phenol ranged from $0.2 \%-2.2 \%$ and gamma-tocopherol ranged from $0.2 \%-0.9 \%$ while vitamin $E$ ranged from $0.4 \%-1.5 \%$. Gamma-sitosterol was the most abundant among all samples with proportions ranging from $1.8 \%-4.9 \%$.

Table 6: Compounds tentatively identified in $W$. ugandensis leaves from different geographical zones.

\begin{tabular}{llllllllll}
\hline $\mathbf{t}_{\mathrm{R}}$ & Tentative identity & \multicolumn{9}{c}{ Area (\%) } \\
\cline { 4 - 10 } & & \multicolumn{3}{c}{ Reference } & \multicolumn{3}{c}{ Samples } \\
\cline { 3 - 10 } & & $\mathbf{S L}$ & $\mathbf{1 L}$ & $\mathbf{2 L}$ & $\mathbf{3 L}$ & $\mathbf{4 L}$ & $\mathbf{5 L}$ & $\mathbf{6 L}$ \\
5.9 & Alpha-cubebene & 0.1 & - & - & - & - & - & - \\
6.3 & Alfa-copaene & 0.1 & - & - & - & 0.1 & - & 0.1 \\
6.3 & Cis muurola-3,5-diene & - & - & - & - & 0.1 & - & - \\
\hline
\end{tabular}

Malay J Pharm Sci, Vol. 19, No. 2 (2021): 23-46 
Table 6: (continued)

\begin{tabular}{|c|c|c|c|c|c|c|c|c|}
\hline \multirow[t]{3}{*}{$t_{R}$} & \multirow[t]{3}{*}{ Tentative identity } & \multicolumn{7}{|c|}{ Area (\%) } \\
\hline & & \multicolumn{3}{|c|}{ Reference } & \multicolumn{4}{|c|}{ Samples } \\
\hline & & SL & $1 \mathrm{~L}$ & $2 \mathrm{~L}$ & $3 \mathrm{~L}$ & $4 \mathrm{~L}$ & $5 \mathrm{~L}$ & $6 \mathrm{~L}$ \\
\hline 6.9 & Caryophyllene & 0.4 & - & 0.3 & - & - & - & - \\
\hline 7.1 & Oxalic acid, 2-ethylhexyl ethyl ester & 0.2 & - & 1.2 & - & - & - & - \\
\hline 7.2 & Beta-bisabolene & 0.4 & - & 1.2 & - & 0.3 & - & - \\
\hline 8.5 & Nerolidol 2 & 1.0 & 0.9 & 1.1 & 0.3 & 0.8 & - & 0.6 \\
\hline 8.6 & Alpha-calacorene & 0.1 & - & - & - & - & - & - \\
\hline 8.9 & Caryophyllene oxide & - & - & 1.3 & - & - & 0.6 & - \\
\hline 9.1 & Thujopsene-I3 & 1.1 & - & - & - & - & - & - \\
\hline 9.4 & Himachala-2,4-diene & 0.5 & - & - & - & - & 0.1 & - \\
\hline 9.9 & Lanceol, cis & 0.3 & - & - & - & 1.1 & - & - \\
\hline 9.9 & Longipinocarveol, trans- & - & - & 0.7 & - & - & - & - \\
\hline 10.0 & Isolongifolene & 1.2 & - & - & - & - & - & 5.5 \\
\hline 10.0 & Africanone & - & - & - & - & 0.2 & - & - \\
\hline 10.1 & (-)-Isolongifolol, methyl ether & - & 0.9 & - & - & 2.2 & - & - \\
\hline 10.1 & $\begin{array}{l}\text { 1,4-Methanoazulene-9-methanol, } \\
\text { decahydro-4,8,8-trimethyl-, } \\
\text { [1S-(1alpha,3abeta,4alpha,8abeta,9R }\end{array}$ & 2.3 & - & 1.5 & - & - & 1.3 & - \\
\hline 10.1 & (-)-Neoclovene-(I), dihydro & - & 0.2 & 0.2 & 0.2 & - & - & - \\
\hline 10.3 & Farnesol isomer & 0.3 & - & - & 0.1 & - & 0.4 & - \\
\hline 10.6 & Gamma-neoclovene & - & 0.5 & - & - & - & - & - \\
\hline 10.7 & Cis-thujopsene & 0.8 & 0.2 & - & - & 0.5 & 0.5 & \\
\hline 10.7 & Alloaromadendrene & - & - & 0.9 & - & - & - & - \\
\hline 11.8 & Nerolidyl acetate & 0.2 & - & 0.1 & - & 1.9 & - & 3.3 \\
\hline 12.0 & Longifolenaldehyde & - & - & - & - & - & 0.3 & - \\
\hline 12.2 & Longifolene-(V4) & - & 0.1 & - & - & - & - & - \\
\hline 12.2 & Isocaryophillene & - & - & - & - & - & - & 0.3 \\
\hline 12.3 & Humulane-1,6-dien-3-ol & 0.7 & - & - & - & 0.1 & - & - \\
\hline 12.5 & Alpha-bisabolol & 0.1 & - & - & - & - & 0.1 & - \\
\hline 12.7 & Alpha-santonin & 0.2 & - & 0.1 & - & - & - & - \\
\hline 12.8 & Bornyl isovalerate & - & - & - & - & - & - & 0.2 \\
\hline 13.2 & $\begin{array}{l}\text { (5aalpha,9abeta,9bbeta.)- } \\
5,5 a, 6,7,8,9,9 a, 9 b-o c t a h y d r o-6,6,9 a- \\
\text { trimethylnaphtho[1,2-c]furan-1-(3H)- } \\
\text { one (drimenin) }\end{array}$ & 0.8 & - & - & - & - & - & - \\
\hline 13.5 & Berkheyaradulene & 0.3 & - & - & - & - & - & - \\
\hline 13.6 & 9-Eicosene, (E) & 0.7 & 1.1 & - & 0.5 & 0.8 & - & - \\
\hline
\end{tabular}


Table 6: (continued)

\begin{tabular}{|c|c|c|c|c|c|c|c|c|}
\hline \multirow[t]{3}{*}{$t_{R}$} & \multirow[t]{3}{*}{ Tentative identity } & \multicolumn{7}{|c|}{ Area (\%) } \\
\hline & & \multicolumn{3}{|c|}{ Reference } & \multicolumn{4}{|c|}{ Samples } \\
\hline & & SL & 1L & $2 \mathrm{~L}$ & $3 \mathrm{~L}$ & 4L & $5 \mathrm{~L}$ & $6 \mathrm{~L}$ \\
\hline 14.1 & Cycloisolongifolene & - & - & - & - & 0.2 & - & 0.2 \\
\hline 14.4 & $\begin{array}{l}\text { Anthracene, } \\
1,2,3,4,5,6,7,8 \text {-octahydro-9,10- } \\
\text { dimethyl }\end{array}$ & - & - & 0.1 & 0.1 & - & - & - \\
\hline 14.7 & Beta-humulene & - & - & - & 0.2 & - & - & - \\
\hline 14.9 & Beta-guaiene & - & - & - & 0.4 & - & - & - \\
\hline 15.0 & Sebacic acid, digeranyl ester & 0.1 & - & - & - & - & - & - \\
\hline 15.3 & Phytol & 0.7 & - & 1.6 & 0.6 & 1.0 & 1.7 & 1.1 \\
\hline 15.4 & Phenol, 2-methoxy & 2.2 & 1.3 & 1.1 & 0.3 & 1.2 & 0.2 & 0.2 \\
\hline 16.4 & Phenol, 4,4-(1-methylethylidene)bis & - & 0.1 & - & - & - & 0.2 & 0.1 \\
\hline 18.8 & Cis-alpha-copaene-8-ol & - & - & - & - & 0.2 & - & - \\
\hline 18.9 & $\begin{array}{l}\text { Pyrimidine-2,4,6-trione, 1-butyl-5-[(2- } \\
\text { piperazin-1-yl-ethylamino)methylene] }\end{array}$ & 0.1 & - & - & - & - & - & - \\
\hline 19.4 & 1-Docosene & 0.6 & 1.0 & - & 0.9 & - & - & - \\
\hline 22.4 & 3-Eicosene, (E) & 0.3 & - & - & - & - & - & - \\
\hline 25.7 & Squalene & 0.2 & 0.2 & 0.3 & - & 0.1 & - & - \\
\hline 28.4 & 1,2-Dihydroharmaline & 0.3 & - & - & - & - & 0.6 & - \\
\hline 28.6 & Gamma-tocopherol & 0.4 & 0.8 & 0.2 & 0.1 & 0.5 & 0.9 & 0.3 \\
\hline 28.9 & Geranyl-alpha-terpinene & 0.3 & - & - & - & - & - & - \\
\hline 28.9 & $\begin{array}{l}\text { Stigmasta-5,22-dien-3-ol, acetate, } \\
\text { (3beta,22Z) }\end{array}$ & - & - & - & 0.3 & - & 0.4 & - \\
\hline 29.9 & Vitamin $\mathrm{E}$ & 1.1 & 0.9 & 1.5 & 0.4 & 3.4 & - & 0.9 \\
\hline 31.4 & Ergost-5-en-3-ol, (3beta) & 0.1 & - & - & - & - & - & - \\
\hline 32.9 & Tetracosane & - & 0.4 & - & - & - & - & - \\
\hline 33.2 & Gamma-sitosterol & 3.9 & - & 1.8 & 2.7 & - & 4.9 & 3.3 \\
\hline 33.6 & 10s,11s-Himachala-3(12),4-diene & - & 0.3 & - & - & - & - & - \\
\hline 33.7 & Phytonadione & 0.1 & - & 0.1 & - & 0.3 & 0.3 & 0.2 \\
\hline 34.8 & $\begin{array}{l}\text { 9,19-Cycloergost- 24(28)-en- } \\
\text { 3-ol, 4,14- dimethyl-, } \\
\text { (3beta,4alpha,5alpha) }\end{array}$ & 0.1 & 0.2 & 0.3 & 0.3 & - & 0.2 & 0.6 \\
\hline
\end{tabular}

Notes: SL-reference sample, L-leaf, 1-6 numerical representation of samples obtained from various geographical locations indicated in Table 1.

It was also observed that majority of the components detected in the leaves were also present in the stem bark. This justifies use of either the leaf or stem bark in managing arthritis and other diseases the plant is said to treat. Use of leaves will aid in conservation of the plant which is endangered because of wide use of stem bark (Kairu et al. 2013). The overlaid chromatograms comparing the reference leaf and others from six geographical 
zones is shown in Figure 5. This study agrees with previous studies that have shown some differences in the chemical composition of similar species from different geographical locations. Yun-Li et al. (2011) established that there was a considerable variation between chemical constituents and species populations of Viscum coloratum collected from different geographical locations. In another study by Singh, Vishwa and Husain (1988), differences in chemical concentrations of Artemisia annua from different locations were established. However, this is the first study that reports chemical similarity and/or variation in W. ugandensis leaf and stem bark from all the geographical zones of the Kenyan flora. The differences may be attributed to minerals in the soils and genetic resources (Sampaio, Edrada-Ebel and Da Costa 2016). Studies by Muchugi et al. (2012) and Onyango et al. (2013) also revealed that there were some genetic variations within $W$. ugandensis species from different geographical locations in Kenya. These differences affect the quality of the material in terms of purity and efficacy since some samples from particular zones have a higher concentration of chemicals that may be responsible for therapeutic activity while others have less. The results would therefore provide the much-needed standards for evaluating quality of samples whose geographical origins are declared.

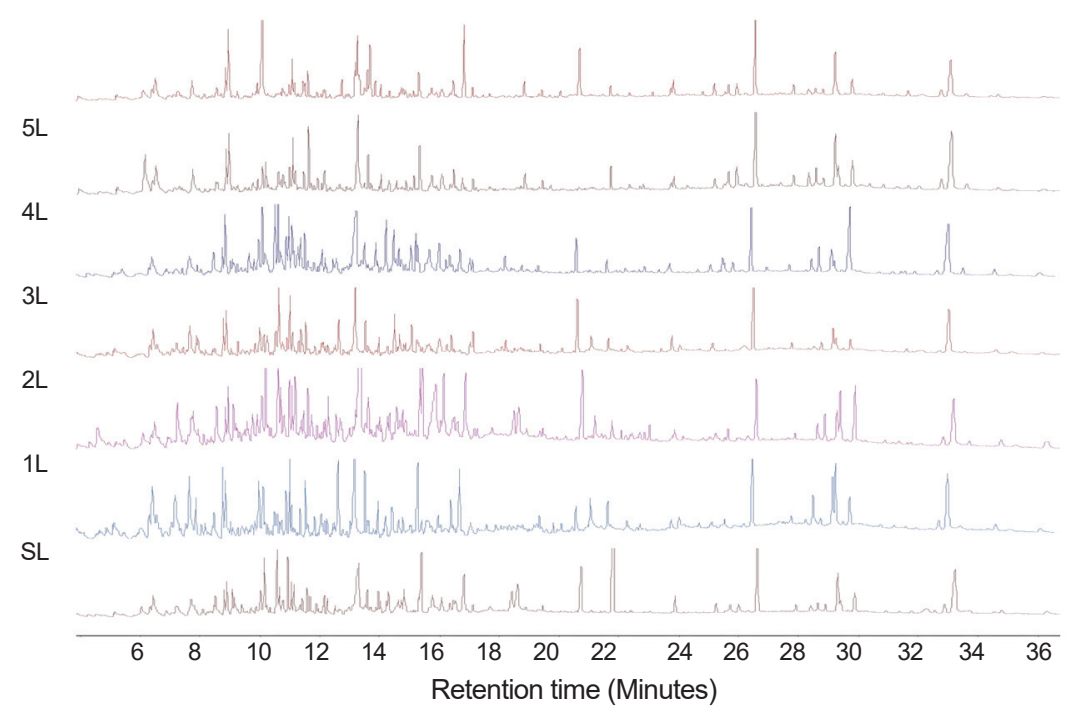

Figure 5: Overlaid gas chromatograms of reference leaf and others from six geographical zones.

Notes: SL - Reference, 1L-6L - Leaf samples from different geographical zones. The overlaid chromatograms show a similarity pattern based on retention time at the horizontal axis thus forming a fingering for identifying $W$. ugandensis leaf based samples.

\section{CONCLUSION}

A GC-MS fingerprinting method for use in quality evaluation of W. ugandensis herbal materials was developed. This method showed more than 100 major components identified for the stem bark and leaf. Based on the number of separated components, $t_{R}$, tentative identity and percent areas, 22 and 38 compounds were selected for use in quality control of the stem bark and leaf, respectively. Most of the identified components were sesquiterpenes 
with few sterols. The relative proportions of stem bark and leaf components ranged from $0.3 \%-2.2 \%$ and $0.1 \%-3.9 \%$, respectively. The GC-MS method demonstrated similarity of $W$. ugandensis from six geographical zones in Kenya by comparing their chemical patterns (fingerprints). The results showed that geographical location influence the number of compounds and thereby quality for both leaf and stem bark. Some compounds were present in almost all samples from various zones though varied in proportions. The five compounds in the stem bark included gamma-sitosterol $(1.0 \%-2.5 \%)$, squalene $(0.2 \%-$ $4.6 \%)$, isolongifolene $(1.2 \%-2.8 \%)$, phenol 2 methoxy $(0.8 \%-1.8 \%)$ and nerolidol $(0.3 \%-$ $1.5 \%)$. Six in the leaf included nerolidol $2(0.3 \%-1.1 \%)$, phytol $(0.6 \%-1.7 \%)$, 2-methoxy phenol $(0.2 \%-2.2 \%)$, gamma tocopherol $(0.2 \%-0.9 \%)$, vitamin $\mathrm{E}(0.4 \%-1.5 \%)$ and gammasitosterol $(1.8 \%-4.9 \%)$.

Results revealed presence of many similar components in the leaf and stem bark. This gives credence to similar therapeutic outcome for both leaf and stem bark. There is need for more studies into confirming the compounds suggested by the developed GC-MS method as a way of validating it.

\section{CONFLICT OF INTEREST}

The authors have no conflict of interest in the reported work.

\section{REFERENCES}

ALAERTS, G., DEJAEGHER, B., SMEYERS, B. J. \& VANDER, H. Y. (2010) Recent developments in chromatographic fingerprints from herbal products: Set-up and data analysis, Combinatorial Chemistry and High Throughput Screening, 13(10): 900-922. https://doi.org/10.2174/138620710793360284

ALAERTS, G., MATTHIJS, N., SMEYERS, V. J. \& VANDER, H. Y. (2007) Chromatographic fingerprint method development of herbal extracts: A screening and optimization methodology on monolithic columns, Journal of Chromatography A, 1172(1): 1-8. https://doi.org/10.1016/j.chroma.2007.07.080

ALAERTS, G., VAN, E. J., PIETERS, S., DUMAREY, M., VAN, N. A. M., GOODARZI, M. et al. (2012) Similarity analysis of chromatographic fingerprints as tools for identification and quality control of green tea, Journal of Chromatography B, 910(1): 61-70. https://doi. org/10.1016/j.jchromb.2012.04.031

AleXANDRE, P., ROgerio, E. L. A., DANEILA, F. P. L. \& CLAUDIA, P. (2009) Preventive and therapeutic anti-inflammatory properties of sesquiterpene alpha-humulene in experimental animals, allergic inflammation, British Journal of Pharmacology, 158(4): 1074-1087. https://doi.org/10.1111/j.1476-5381.2009.00177.x

BEENTJE, H. J. (1994) Kenya trees, shrubs and lianas. (Nairobi, Kenya: The National Museums of Kenya).

DHARANI, N. (2002) Field guide to trees and shrubs of East Africa, $2^{\text {nd }}$ edition (Capetown, South Africa: Random Struik Publishers).

Malay J Pharm Sci, Vol. 19, No. 2 (2021): 23-46 
DRAGE, S., MITTER, B., TRÖLS, C., MUCHUGI, A., JAMNADASS, R. H., SESSITSCH, A. et al. (2014) Antimicrobial drimane sesquiterpenes and their effect on endophyte communities in the medical tree Warburgia ugandensis, Frontiers in Microbiology, 5: 13. https://doi.org/10.3389/fmicb.2014.00013

EUROPEAN MEDICINES AGENCY (EMEA) (2011). Guidelines on quality of herbal medicinal products/traditional medicinal products. Review European agency for medicinal products, pp. 1-13 (UK, London: EMEA London).

FAN, G., YI-ZENG, L. \& REISHAN, X. (2003) Information theory applied to chromatographic fingerprint of herbal medicines for quality control. Journal of Chromatography $A, 1002(1-2)$ : 25-40. https://doi.org/10.1016/S0021-9673(03)00648-4

FAN, X., CHENG, Y., YE, Z., LIN, R. \& QIAN, Z. (2006) Multiple chromatographic fingerprinting and its application to the quality control of herbal medicines, Analytica Chimica Acta, 555: 217-224. https://doi.org/10.1016/j.aca.2005.09.037

HENDRIKS, M. M. W. B., CRUZ-JUAREZ, L., DE BONT, D. \& HALL, R. D. (2005) Preprocessing and exploratory analysis of chromatographic profiles of plant extracts, Analytica Chimica Acta, 545(1): 53-64. https://doi.org/10.1016/j.aca.2005.04.026

HUSAN, T., BSAK, T. \& ABDULGANI, T. (2014) Cytotoxic and cytogenetic effects of -copaene on rat neurone and $\mathrm{N}_{2}$ a neuroblastoma cell lines, Cellular and Molecular Biology, 69: 936-942. https://doi.org/10.2478/s11756-014-0393-5

JI, B., XU, Q. S., HU, Y. Z. \& HEYDEN, Y. (2005) Development, optimization and validation of a fingerprint of Ginkgo biloba extracts by high-performance liquid chromatography. Journal of Chromatography A, 1066(1-2): 97-104. https://doi.org/10.1016/j.chroma.2005.01.035

JIAN, G., RUI, T. \& SHENGMAO, L. (2010) Comprehensive principle of HPLC fingerprint in the construction and evaluation of Chinese herbal medicines. North American Journal of Medicine and Science, 3(2): 107-112.

JIANQ, Q., CHRISTEN, S., SHIQENAQA, M. K. \& AMES, B. N. (2001) Tocopherol, the major form of vitamin $\mathrm{E}$ in the US diet deserves more attention, The American Journal of Clinical Nutrition, 74(6): 714-722. https://doi.org/10.1093/ajcn/74.6.714

KAIRU, A., GICHUKI, N., KANYA, J. \& KINDT, R. (2013) Disappearing medicinal plants in Mount Kenya forests. A case study of East African greenheart (Warbugia ugandensis Sparague), Journal of Herbal Medicine, 2: 159-165.

KHODDAMI, A., MEREDITH, A. W. \& THOMAS, H. R. (2013) Techniques for analysis of plant phenolic compounds, Molecules, 18(2): 2328-2375. https://doi.org/10.3390/ molecules18022328

KIOY, D., GRAY, A. L. \& WATERMAN, P. G. (1990) A comparative study of the stem bark drimane sesquiterpenes and leaf volatile oils of Warburgia ugandensis and Warburgia stuhlmanii, Phytochemistry, 29(11): 3535-3538. https://doi.org/10.1016/00319422(90)85270-P 
KOWALYA, R. \& ELANGOVAN, N. Y. (2013) In vitro antioxidant and free radical scavenging activity of isolongifolene from Murraya koenigii leaves, Chemistry, 4: 276-279.

LACROIX, D., PRADO, S., KAMOGA, D., KASENENE, J., NAMUKOBE, J., KRIEF, S. et al. (2011) Antiplasmodial and cytotoxic activities of medicinal plants traditionally used in the village of Kiohima, Uganda, Journal of Ethnopharmacology, 113(2): 850-855. https:// doi.org/10.1016/j.jep.2010.11.013

LEKHOOA, M., ANDREW, W., JAN, J. B., MOTLALEPULA, C. M. \& DUDUZILE, M. (2012) Evaluation of traditional medicine I; Identification of phela using different chromatographic techniques, African Journal of Traditional, Complementary and Alternative Medicines, 9(3S): 27-39. https://doi.org/10.4314/ajtcam.v9i3S.5

LIANG, X., XIE, P. \& CHAN, K. (2004). Quality control of herbal medicines. Journal of Chromatography B, 812(1-2): 53-70. https://doi.org/10.1016/S1570-0232(04)00676-2

MASHIMBYE, M. J., MAUMELA, M. C. \& DREWES, S. E. (1999) A drimane sesquiterpinoid lactone from Warburgia salutaris, Phytochemistry, 51(3): 435-438. https://doi.org/10.1016/ S0031-9422(98)00753-5

MBWAMBO, Z. H. \& ERASTO, P. (2009) Antimicrobial and cytotoxic activities of fresh leaf extracts of Warbugia ugandensis, Tanzania Journal of Health Research, 11(2): 75-78. https://doi.org/10.4314/thrb.v11i2.45205

MUCHUGI, A., JAMNADA, R. H., SIMONS, A. J. \& RUKUNGA, J. (2006) In vitro assessment of antimalarial activity of raw bark and leave extracts of Warbugia ugandensis, KEMRI/ ICRAF project report.

MUCHUGI, A., ROLAND, K., MULUVI, G., MUGE, E., KIPRUTO, H. \& JAMNADES, R. H. (2012) Genetic variation of Kenyan populations of Warbugia ugandensis, an important East African highlands medicinal tree species, Journal of Life Sciences, 4(4): 97-105. https://doi. org/10.1080/09751270.2012.11885201

MUTHAURA, C. N., RUKUNGA, G. M. \& CHHABRA, S. C. (2007) Antimalarial activity of some plants traditionally used in treatment of malaria in Kwale district of Kenya, Journal of Ethnopharmacology, 112(3): 545-551. https://doi.org/10.1016/j.jep.2007.04.018

MUTHAURA, C. N., KERIKO, J. M., REUSE, S., YENESEW, A. \& RUKUNGA, G. M. (2011) Investigation of some medicinal plants used for treatment of Malaria in Kenya as potential sources of antimalarial drugs, Experimental Parasitology, 127(3): 609-626. https://doi. org/10.1016/j.exppara.2010.11.004

NAIR, M. S. \& BASIKE, D. V. (1993) Bioconversion of arteannuin b to artemisinin, Journal of Natural Products, 56(9): 1559-1566. https://doi.org/10.1021/np50099a015

NATIONAL CENTER FOR BIOTECHNOLOGY INFORMATION (2020) PubChem Compound Summary for CID 5284507, Nerolidol. https://pubchem.ncbi.nlm.nih.gov/ compound/nerolidol (9 October 2020).

Malay J Pharm Sci, Vol. 19, No. 2 (2021): 23-46 
NEERAJ, C. \& BHUPINDER, S. S. (2011) An overview of advances in the standardization of herbal drugs, Journal of Pharmaceutical Education and Research, 2(2): 55-70.

NGURE, P. K. \& TONUI, W. K. (2009) In vitro antileishmanial activity of extracts of Warbugia ugandensis (Canellaceae), a Kenyan medicinal plant, Journal of Medicinal Plant Research, 3: 61-66.

OLILA, D. \& OLWA, O. (2001) Antibacterial and antifungal activities of extracts of Zanthoxylum chalebeum and Warbugia ugandensis, Ugandan medicinal plants, African Health Sciences, 1: 66-72.

ONYAMBU, M. O. (2016) Development of chromatographic fingerprinting and other quality evaluation methods for warburgia ugandensis sprague herbal materials, PhD thesis., Kenyatta University, Kenya.

ONYAMBU, M. O., GIKONYO, N. K., HUDSON, N. \& THOITHI, G. (2020) Macroscopic and microscopic features of diagnostic value for Warbugia ugandensis, Sparague leaf and stem-bark herbal materials, Journal of Pharmacognosy and Phytotherapy, 112(2): 36-43. https://doi.org/10.5897/JPP2019.0569

ONYAMBU, M. O., GIKONYO, N. K., NYAMBAKA, H. N. \& THOITHI, G. (2019) A review of trends in herbal drugs standardization, regulation and integration to the national healthcare systems in Kenya and the globe, International Journal of Pharmacognosy and Chinese Medicine, 3(3): 1-13.

ONYAMBU, M. O., CHEPKWONY, H. K., THOITHI, G. N., OUYA, G. O. \& OSANJO, G. O. (2013) Microbial quality of unregulated herbal medicinal products in Kenya, African Journal of Pharmacology and Therapeutics, 2(3): 70-75.

ONYANGO, N. O., MUCHUGI, A., MUGE, E., OMONDI, B. A. \& JAMNADAS, R. (2013) Identification of specific markers linked to regional differentiation of $W$. ugandensis, Journal of Life Sciences, 5(1): 29-40. https://doi.org/10.1080/09751270.2013.11885212

SAMPAIO, B. L., EDRADA-EBEL, R. \& DA COSTA, F. B. (2016) Effect of the environment on the secondary metabolic profile of Tithonia diversifolia: A model for environmental metabolomics of plants, Scientific Reports, 6: 29265. https://doi.org/10.1038/srep29265

SINGH, A., VISHWA, K. R. A. \& HUSAIN, A. (1988) Evaluation of Artemisia annua production for higher artemisinin production, Planta Medica, 475-476. https://doi. org/10.1055/s-2006-962515

SUE, E., MESTIN, T. \& INGA, H. (1995) Flora of Ethiopia and Eritrea, Canellaceae to Euphoboaceae. Addis Ababa, Ethiopia: Addis Ababa University Ethiopia and Uppsalla University Sweden.

TISTAERT, C., DEJAEGHER, B. \& VANDER, H. Y. (2011) Chromatographic separation techniques and data handling methods for herbal fingerprints: A review, Analytica Chimica Acta, 690(2): 148-161. https://doi.org/10.1016/j.aca.2011.02.023 
VENKATA, R. B., SAMUEL, L. A., PARDHA, S. M., NARASHIMA, R. B., NAGA, V. K., SUDHAKAR, M. et al. (2012) Antibacterial, antioxidant activity and GC-MS analysis of Eupatorium odoratum, Asian Journal of Pharmaceutical and Clinical Research, 12: 99-106.

WORLD HEALTH ORGANIZATION (WHO). (1998) Quality control guidelines for medicinal plant materials, pp. 1-111 (Geneva: World Health Organization).

WORLD HEALTH ORGANIZATION (WHO). (2002) General guidelines for methodologies on research and evaluation of traditional medicine. (Geneva: World Health Organization)

WORLD HEALTH ORGANIZATION (WHO). (2003) WHO guidelines on good agricultural practices (GACP) for medicinal plants. (Geneva: World Health Organization).

WUBE, A. A. \& BUCAR, F. (2005) Sesquiterpenes from Warbugia ugandensis and their antimycobacterial activity, Phytochemistry, 66: 2309-2315. https://doi.org/10.1016/j. phytochem.2005.07.018

XIE, P. S., CHEN, S. B., LIANG, Y. Z., WANG, X. H., TIAN, R. T. \& ROY, U. (2006) Chromatographic fingerprint analysis, a rational approach for quality assessment for traditional Chinese medicine, Journal of Chromatography A, 1112: 171-180. https://doi. org/10.1016/j.chroma.2005.12.091

XU, M., LITAUDON, M., KRIEF, S., MARTIN, M. T., KASENENE, J., KIREMIRE, B. et al. (2009) Ugandenial A, a new drimane type sesquiterpene from Warbugia ugandensis, Molecules, 14(10): 3844-3854. https://doi.org/10.3390/molecules14103844

YUN-LI, Z., RON, G., HUA, F., HUNG, X. Y., MIA, Y., KAI, S. B. \& ZHI, G. U. (2011) Development of fingerprints for quality evaluation of Viscum coloratum by high-performance liquid chromatography, Journal of Pharmaceutical Analysis, 1: 113-118. https://doi. org/10.1016/S2095-1779(11)70020-X

ZOU, H., DUAI, Q. \& ZHANG, X. L. (2012) Quality control methodology and their application in analysis on HPLC fingerprint spectra of herbal medicines, Chromagraphy Research International, 2012: 1-12. https://doi.org/10.1155/2012/851792

Malay J Pharm Sci, Vol. 19, No. 2 (2021): 23-46 